\title{
INOVAÇÕES PÓS-POSITIVISTAS NOS PARADIGMAS DO DIREITO ADMINISTRATIVO BRASILEIRO
}

\author{
POST-POSITIVISM INOVATIONS ON BRAZILIAN ADMINISTRATIVE LAW \\ PRINCIPLES
}

\author{
INNOVACIONES POST-POSITIVISTAS EN LOS PARADIGMAS DEL DERECHO \\ ADMINISTRATIVO BRASILEÑO
}

\begin{abstract}
LUCIANA GASPAR MELQUIADES DUARTE
Doutora em Direito pela Universidade Federal de Minas Gerais. Professora Adjunta de Direito Constitucional e Administrativo da Universidade Federal de Juiz de Fora, Pesquisadora, Professora do Mestrado em Direito e Inovações da Faculdade de Direito da UFJF e ex-Procuradora do Município de Juiz de Fora. Juiz de Fora, Minas Gerais, Brasil. http://lattes.cnpq.br/9612622153460207 / http://orcid.org/0000-0002-1321-5313 / lg.melquiades@uol.com.br
\end{abstract}

GABRIEL Coutinho GaliL Graduando e Bolsista de Iniciação Científica na Universidade Federal de Juiz de Fora. Juiz de Fora, Minas Gerais, Brasil. http://lattes.cnpq.br/7979287057295850 / http://orcid.org/0000-0003-4435-5738 / gcgalil@gmail.com

\begin{abstract}
RESUMO
O descompasso entre uma relevante parte da doutrina administrativista pátria e os novos paradigmas trazidos pelo Pós-Positivismo justificou o presente trabalho, que tem o escopo de realizar a revisão dos paradigmas do Direito Administrativo sob o lume deste marco teórico, marcadamente pelas obras de Robert Alexy e Ronald Dworkin. Dessa maneira, através do método dedutivo de pesquisa, realizou-se a releitura histórica e científica de quatro pilares da dogmática administrativa: o princípio da legalidade, o princípio da supremacia do interesse público, a discricionariedade e $\mathrm{o}$ ato administrativo. Através deste esforço, propõe-se a adaptação dos referidos pilares aos mandamentos constitucionais e à consolidação do Estado Democrático de Direito.
\end{abstract}

Palavras-chave: Direito Administrativo; Discricionariedade; Interesse público; Juridicidade; Processo administrativo.

\begin{abstract}
The justification of this paper is the mismatch between a great part of the Brazilian Administrative Law literature and the new scientific referential brought by Post-Positivism, and its proposal is to review the main principles of the Administrative Theory under the post-positivist perspective, mainly guided by Robert Alexy's and Ronald Dworkin's work. Thus, through the deductive research method, the four core pillars of Administrative Law were historically and scientifically reviewed: the legality principle, the supremacy of public interest principle, the administrative discretion and the administrative act. By this effort, it suggest the adaptation of the referred pillars to the constitutional principles and the consolidation of the Democratic State of Law.
\end{abstract}

Keywords: Administrative Law; Discretionary power; Public interest; Jurisdicity; Administrative process.

\section{RESUMEN}

El desajuste entre una parte relevante de la doctrina administrativista patria y los nuevos paradigmas traídos por el Post-Positivismo justificó el presente trabajo, que tiene el propósito de realizar la revisión de los paradigmas del Derecho Administrativo bajo el lumen de este marco teórico, marcadamente por las obras de Robert Alexy Y Ronald Dworkin. De esta manera, a través del método deductivo de investigación, se realizó la relectura histórica y científica de cuatro pilares de la dogmática administrativa: el principio de la legalidad, el principio de la supremacía del interés 
público, la discrecionalidad y el acto administrativo. A través de este esfuerzo, se propone la adaptación de dichos pilares a los mandamientos constitucionales ya la consolidación del Estado Democrático de Derecho.

Palabras clave: Derecho Administrativo; Discriminación; Interés público; Juridicidad; Procedimiento administrativo.

\section{SUMÁRIO}

INTRODUÇÃO; 1 TRANSFORMAÇÕES HISTÓRICAS DO DIREITO ADMINISTRATIVO; 2 OS PARADIGMAS DO DIREITO ADMINISTRATIVO; 2.1 Legalidade e Juridicidade; 2.2 A Supremacia do Interesse Público; 2.3 A discricionariedade administrativa; 2.4 Do ato ao processo administrativo; CONCLUSÃO; REFERÊNCIAS.

\section{INTRODUÇÃO}

O presente trabalho propõe-se a realizar, sob a égide do Pós-Positivismo, uma releitura dos postulados que, apesar de arcaicos, são apresentados, por parte da doutrina administrativista, como base do regime jurídico publicístico, a exemplo do princípio da legalidade, do princípio da supremacia do interesse público, da discricionariedade e da atuação administrativa actocêntrica.

A elaboração do trabalho se deu através da análise de parte da literatura nacional sobre o Direito Administrativo, na qual se identificou uma abordagem positivista da temática aludida. Assim, realizou-se uma busca histórica para identificar a gênese desse enfoque doutrinário, que confere ensejo ao exercício da atividade administrativa de maneira unilateral e autoritária. A partir da identificação do seu descompasso com os princípios constitucionais que norteiam o sistema jurídico pátrio, sob o referencial do Pós-Positivismo e com o intuito de revisitar os fundamentos jurídicos da atividade administrativa, realizou-se a pesquisa ora relatada, valendose do método dedutivo de pesquisa.

O referencial teórico apontado visa evidenciar a irradiação dos direitos fundamentais por todo o ordenamento jurídico, inclusive no Direito Administrativo. Dessa maneira, através da incidência da carga axiológica dos princípios constitucionais que veiculam tais direitos e da utilização da argumentação jurídica, objetiva-se a colaboração para a construção de uma Administração Pública que se pauta na racionalidade e na pretensão de correção. Assim, sob o lume da centralidade dos direitos fundamentais e da argumentação racional, procurar-se-á adequar os postulados do Direito Administrativo ao Estado Democrático de Direito instituído constitucionalmente. 


\section{TRANSFORMAÇÕES HISTÓRICAS DO DIREITO ADMINISTRATIVO}

O surgimento do Estado de Direito teve como marco ideológico o movimento Iluminista e como marco político as Revoluções Liberais ocorridas nos séculos XVII e XVIII. A centralidade do discurso filosófico trazida pelos contratualistas é assumida pela figura do homem e dos direitos a ele inerentes, os quais devem ser maximamente preservados no pacto social. Esse debate transforma a forma de organização social presente na Europa da Idade Moderna, o Absolutismo, que tinha como figura central o Monarca e a atuação estatal ligada diretamente a seu arbítrio.

A efetivação dos direitos naturais do homem passa a ser, então, o escopo máximo do Estado, que, visando assegurar a liberdade e segurança dos indivíduos, adota a Separação dos Poderes, sistematizada por Montesquieu. O sistema tripartido permite a positivação da vontade geral da comunidade através dos representantes democraticamente eleitos para o Poder Legislativo, responsável pela edição de leis que vincularão os atos do Poder Executivo. A anterioridade e a abstração das leis permitiriam previsibilidade e a objetividade da atuação estatal, assegurando os princípios de liberdade, igualdade (ainda que somente formal, naquele momento) e segurança jurídica. Os casos de abuso por parte do Executivo seriam julgados por um terceiro poder, o Judiciário, completando o mecanismo de freios e contrapesos.

A doutrina administrativa clássica atribui a gênese do Direito Administrativo ao próprio surgimento do Estado de Direito, uma vez que é neste episódio que surge a vinculação da atuação estatal à lei (Rule of $L a w)$ e a gradual consolidação de normas que irão pautá-la, formando a base do Direito Administrativo ${ }^{1}$. Como explicar, então, que, de uma origem democrática, tenha surgido uma cultura estatal presente em grande parte dos Estados nos séculos XIX e XX, que se fundamenta em postulados provenientes do próprio movimento pósrevolucionário francês, como a supremacia do interesse público, discricionariedade administrativa e insindicabilidade do mérito administrativo? A resposta encontrada pela doutrina lusófona é chamada de ilusão garantística da gênese ${ }^{2}$.

Segundo essa releitura histórica, a origem do Direito Administrativo deu-se pela edição de diversas decisões pelo Conselho de Estado francês, que visavam afastar o Executivo do

\footnotetext{
${ }^{1}$ DI PIETRO, Maria Sylvia Zanella. Direito Administrativo. 27. ed. São Paulo: Atlas, 2014. p. 2.

2 OTERO, Paulo. Legalidade e Administração Pública - O Sentido da Vinculação Administrativa à Juridicidade apud BINEMBOJM, Gustavo. Da Supremacia do Interesse Público ao Dever de Proporcionalidade: Um novo paradigma do Direito Administrativo. Quaestio luris. Rio de Janeiro, v. 01, n. 02, 2005. Disponível em:

http://www.e-publicacoes.uerj.br/index.php/quaestioiuris/article/view/11615/9099. Acesso em: 01 maio 2016.
} 
controle judicial, devido à forte desconfiança em relação ao Judiciário conservador, que se contrapunha aos revolucionários ${ }^{3}$. A exclusão da apreciação da atividade administrativa pelo Poder Judiciário na França se dá de forma expressa no artigo 13 da Lei $n^{\circ} 16-24$ de agosto de $1790^{4}$, que estabeleceu inclusive sanções aos juízes que descumprissem essa orientação.

Dessa maneira, as diversas normas que garantiam à Administração um regime jurídico diferenciado do que regia as relações privadas foram uma criação do próprio Poder Executivo, no seio do Conselho de Estado Francês, que se mostrou insubmisso ao Legislativo, apesar da Separação dos Poderes, e ao Judiciário, pela manutenção do contencioso administrativo já existente no regime absolutista. A existência de uma jurisdição administrativa autônoma foi determinante para a criação pretoriana de normas que favoreceram a Administração e consolidaram uma autonomia substancial para o Direito Administrativo ${ }^{5}$. A preservação desses postulados que garantem ao Administrador uma atuação, muitas vezes, unilateral não se limitou ao século $X X$, estando presente em diversos manuais de Direito Administrativo atuais, que os atribuem a uma gênese democrática e garantística deste ramo do Direito.

Em sentido diverso é a posição de Gabardo e Hachem, os quais defendem que o pretenso autoritarismo identificado na gênese do Direito Administrativo não se sustentaria dentro daquilo que denominam de uma análise histórica adequada, uma vez que suas raízes foram o contraponto ao regime autoritário ${ }^{6}$. Os autores indicam, ainda, que o autoritarismo presente no Direito Administrativo Brasileiro não teria sua fonte na pretensa autonomia desenvolvida no âmbito do Contencioso Administrativo Francês, uma vez que ele não se instaurou no Brasil, mas sim no caráter personalista e antirrepublicano da Administração Brasileira ${ }^{7}$.

\footnotetext{
${ }^{3}$ MELLO, Celso Antônio Bandeira de. Curso de Direito Administrativo. 27. ed. São Paulo: Malheiros, 2010. p. 44.

${ }^{4}$ FRANÇA. Ministério da Justiça. L'œuvre révolutionnaire: les fondements de la justice actuelle. Disponível em: http://www.justice.gouv.fr/histoire-et-patrimoine-10050/la-justice-dans-lhistoire10288/loeuvre-revolutionnaire-les-fondements-de-la-justice-actuelle-11909.html. Acesso em: 01 maio 2016.

${ }^{5}$ ESTORNINHO, Maria João. Réquiem pelo Contrato Administrativo. Lisboa: Almedina, 2003. p. 25.

${ }^{6}$ GABARDO, Emerson; HACHEM, Daniel Wunder. 0 suposto caráter autoritário da supremacia do interesse público e das origens do direito administrativo: uma crítica da crítica. In: BACELLAR FILHO, Romeu Felipe; HACHEM, Daniel Wunder (Coord.). Direito administrativo e interesse público: estudos em homenagem ao Professor Celso Antônio Bandeira de Mello. Belo Horizonte: Fórum, 2010. p. 170.

${ }^{7}$ GABARDO, Emerson; HACHEM, Daniel Wunder. O suposto caráter autoritário da supremacia do interesse público e das origens do direito administrativo: uma crítica da crítica. In: BACELLAR FILHO, Romeu Felipe; HACHEM, Daniel Wunder (Coord.). Direito administrativo e interesse público: estudos em homenagem ao Professor Celso Antônio Bandeira de Mello. Belo Horizonte: Fórum, 2010. p. 157.
} 
Enfrentando a primeira crítica levantada pelos autores, deve-se destacar que o simples fato de o surgimento do Direito Administrativo ter ocorrido no contexto de superação do Regime Absolutista não impede que ele, também, incorpore o caráter autoritário apontado por Binembojm ${ }^{8}$. Avançando ao segundo argumento apresentado, não parece possível realizar a dissociação completa entre os fatores elencados na ilusão garantística da gênese e na utilização antidemocrática do interesse público e do aparato estatal no contexto brasileiro, uma vez que o primeiro fundamenta, ainda que parcialmente, a ocorrência do segundo.

Dessa maneira, os autores constroem relevante crítica à transposição literal da narrativa presente na doutrina lusófona para a realidade brasileira ${ }^{9}$, usualmente desconsiderando as peculiaridades de cada contexto histórico. De igual maneira, é relevante a narrativa que considera os aspectos singulares da realidade brasileira. No entanto, ainda que a versão portuguesa da história possua algumas impropriedades, o fato é que a criação pretoriana do Direito Administrativo ensejou a criação de postulados que embasaram a atuação administrativa personalística brasileira, principalmente devido a sua repetição acrítica por parte significativa da doutrina administrativista nacional.

Assim, ainda que ocorra divergência sobre a origem histórica dos postulados autoritários do Direito Administrativo, esses permanecem sendo reproduzidos nos respectivos manuais, como será visto no presente trabalho, e utilizados na prática administrativista e judicial brasileira, resultando na manutenção de uma atuação estatal antidemocrática. A partir da subsistência desses postulados e a partir dos princípios constitucionais positivados na Constituição ${ }^{10}$, considerados no espectro do Pós-Positivismo, deve-se realizar uma releitura em busca de uma atuação administrativa conforme os preceitos de um Estado Democrático de Direito.

Ressalte-se, ainda, que Augustín Gordillo ${ }^{11}$ considera equivocado atribuir o nascimento do Direito Administrativo ao surgimento do Estado de Direito, uma vez que, nesta oportunidade, assistiu-se tão somente à sua autonomização científica, e não o surgimento em si de normas

\footnotetext{
8 BINEMBOJM, Gustavo. Da Supremacia do Interesse Público ao Dever de Proporcionalide: Um novo paradigma do Direito Administrativo. Quaestio luris. Rio de Janeiro, v. 01, n. 02, 2005. Disponível em: http://www.e-publicacoes.uerj.br/index.php/quaestioiuris/article/view/11615/9099. Acesso em: 01 maio 2016.

${ }^{9}$ GABARDO, Emerson; HACHEM, Daniel Wunder. 0 suposto caráter autoritário da supremacia do interesse público e das origens do direito administrativo: uma crítica da crítica. In: BACELLAR FILHO, Romeu Felipe; HACHEM, Daniel Wunder (Coord.). Direito administrativo e interesse público: estudos em homenagem ao Professor Celso Antônio Bandeira de Mello. Belo Horizonte: Fórum, 2010. p. 157.

${ }^{10}$ BRASIL. Constituição da República Federativa do Brasil de 03 de Outubro de 1988. 34. ed. São Paulo: Saraiva, 2004.

${ }^{11}$ GORDILLO, Augustín. Tratado de Derecho Administrativo. 7. ed. Belo Horizonte: Del Rey, 2003.
} 
administrativas, que sempre teriam existido, com qualquer organização administrativa ou modelo de Estado, ainda que voltadas apenas para uma função de polícia. Para Ruy Cirne Lima ${ }^{12}$, inclusive em textos jurídicos romanos já se encontrava a menção ao interesse público. Desse modo, é importante ressaltar que, ao contrário do que estabelece a doutrina clássica, o marco histórico do Estado de Direito foi essencial para a consolidação do Direito Administrativo como ciência, mas não necessariamente para seu surgimento normativo.

O Pós-Positivismo teve seu marco histórico inicial no continente europeu no contexto do pós-guerra ${ }^{13}$. Os episódios que precederam seu surgimento foram de grandes devastações e de violações aos direitos humanos sob o respaldo da legalidade, em decorrência da construção jusfilosófica positivista, que visava afastar do Direito qualquer juízo moral. Dessa maneira, a colaboração dos diversos autores, principalmente da Filosofia do Direito, foi no sentido de reaproximar a ciência jurídica dos valores de moral e justiça. Não ocorreu, no entanto, um retrocesso ao jusnaturalismo, uma vez que essa reaproximação foi construída em cima de fundamentos científicos. A carga axiológica que incide sobre o ordenamento jurídico tem sua origem em valores positivados nele mesmo, na forma de princípios, que devem ser interpretados de forma racional e fundamentada, através dos novos mandamentos hermenêuticos também construídos sob essa égide. 0 grande trunfo desse marco é a centralidade axiológica do princípio da dignidade da pessoa humana, que se torna a pedra de toque de diversos sistemas jurídicos após 1945, incluindo a Constituição Brasileira de 1988, e a consequente centralidade jurídica dos direitos fundamentais ${ }^{14}$ que dela derivam. De igual maneira, esse movimento é corolário de outro grande avanço científico, que também é um pilar do presente trabalho, a normatividade constitucional $^{15}$.

\section{OS PARADIGMAS DO DIREITO ADMINISTRATIVO}

Como foi exposto acima, o Direito Administrativo teve, desde a sua gênese, uma marcada autonomia em relação aos outros ramos do Direito, estabelecendo, para a

\footnotetext{
${ }^{12}$ LIMA, Ruy Cirne. Sistema de Direito Administrativo Brasileiro. Porto Alegre: Gráfica Santa Maria, 1953.

${ }^{13}$ BARROSO, Luis Roberto. Direito Constitucional Contemporâneo. 4. ed. São Paulo: Saraiva, 2013.

14 BINEMBOJM, Gustavo. Uma Teoria do Direito Administrativo: direitos fundamentais, democracia e constitucionalização. 2. ed. Rio de Janeiro: Renovar, 2008.

${ }^{15}$ HESSE, Konrad. A Força normativa da Constituição. Tradução de Gilmar Ferreira Mendes. Porto Alegre: Sergio Antonio Fabris, 1991.
} 
Administração, uma posição privilegiada em relação ao particular. No Brasil, a doutrina importou os postulados formulados pelos tribunais administrativos franceses, uma vez que o Conselho de Estado aqui exercia função somente consultiva e, ao contrário do que ocorreu na França, foi adotada a unidade de jurisdição, sob influência do common law ${ }^{16}$.

No ordenamento jurídico brasileiro, o Direito Administrativo é transformado com a promulgação da atual Constituição ${ }^{17}$, que prevê diversos dispositivos específicos afeitos à atuação estatal e seus princípios basilares. No entanto, a doutrina pátria, em grande parte, mostra-se anacrônica, deixando de reconhecer os impactos dos novos princípios constitucionais, tal qual o princípio democrático e o princípio da centralidade dos direitos fundamentais ${ }^{18}$, como parte da dogmática administrativista, concomitantemente com a manutenção dos arcaicos postulados que garantem à Administração uma atuação desconforme ao regime republicano instituído. Ademais, com a incidência do viés teórico do Pós-Positivismo, impõe-se uma revisitação dos preceitos do Direito Administrativo sob o paradigma da supremacia constitucional e de sua normatividade.

\subsection{Legalidade e Juridicidade}

O escopo primeiro do Estado de Direito é a vinculação da atividade do Estado à previsão normativa, anterior e abstrata. Essa ideia apresenta-se como fundamento do princípio da legalidade. Ocorre que o desenvolvimento desse princípio guiou-se predominantemente pela doutrina positivista, tendo como referencial o ordenamento jurídico como sistema estático e escalonado.

O modelo kelseniano é marcado pela valoração do aspecto formal das normas, por considerar como seu pressuposto de validade a compatibilidade com a norma imediatamente superior $^{19}$. Assim, a Administração estaria vinculada somente ao nível normativo infraconstitucional, e não ao sistema jurídico em sua integralidade. Como exemplo dessa corrente de entendimento, pode-se citar Bandeira de Mello, que assim versa sobre a legalidade: “a consagração da ideia de que a Administração Pública só pode ser exercida na conformidade

\footnotetext{
${ }^{16}$ DI PIETRO, Maria Sylvia Zanella. Direito Administrativo. 27. ed. São Paulo: Atlas, 2014. p. 26.

17 DI PIETRO, Maria Sylvia Zanella. Direito Administrativo. 27. ed. São Paulo: Atlas, 2014. p. 26.

18 BARROSO, Luis Roberto. Direito Constitucional Contemporâneo. 4. ed. São Paulo: Saraiva, 2013. p. 344.

${ }^{19}$ KELSEN, Hans. Teoria Pura do Direito. 8. ed. São Paulo: Martins Fontes, 2009.
} 
da lei e que, de conseguinte, a atividade administrativa é atividade sublegal, infralegal, consistente na expedição de comandos complementares à lei"20.

Deve-se ressaltar o fundamento histórico de tal interpretação do princípio da legalidade, tendo em vista que, no surgimento do Estado de Direito, a Constituição ocupava-se quase exclusivamente de matéria organizacional do Estado, sendo os outros assuntos tratados de maneira infraconstitucional ${ }^{21}$. Também se destaca o fato de o surgimento do Estado de Direito ter se dado em meio à doutrina do Liberalismo Político, que prezava predominantemente pelos direitos de defesa e uma intervenção mínima do Estado. Assim, a vinculação do Estado à legalidade era corolário do principio da autonomia da vontade dos administrados. Ainda neste sentido, destacam-se duas correntes diversas sobre a vinculação à lei, desenvolvidas no século XIX. Na primeira corrente, de origem francesa, a atividade administrativa era integralmente vinculada à lei, ensejando a concepção de vinculação positiva à lei. Em sentido diverso, na Alemanha, desenvolveu-se a corrente da vinculação negativa à lei, onde ela era considerada o limite da atividade estatal, que por sua vez era livre, respeitados esses limites e o interesse público ${ }^{22}$.

A evolução histórica, no entanto, trouxe outros modelos de Estado, situados em realidades sociais cada vez mais complexas. O modelo do Welfare State trouxe consigo a imposição de um número crescente de obrigações prestacionais por parte do Estado, dificultando a previsão legal de cada situação em que o Estado deveria atuar. Assim, no século XX, ocorreu o que é denominado de a crise da lei formal.

Esse fenômeno histórico tem duas principais causas. A primeira delas pode-se reputar na consequência do Positivismo Normativista, que desvinculou a lei de qualquer conteúdo axiológico, afastando-a dos ideais de Justiça. Como resultado, a lei perdeu sua superioridade hierárquica em virtude de seu caráter meramente formal ${ }^{23}$. Concomitantemente à supracitada assunção do Estado Social e seu consequente aumento dos encargos do Legislativo, resulta um overload deste poder, que se torna incapaz de responder a todas as demandas da sociedade ${ }^{24}$.

\footnotetext{
${ }^{20}$ MELLO, Celso Antônio Bandeira de. Curso de Direito Administrativo. 27. ed. São Paulo: Malheiros, 2010. p. 100.

${ }^{21}$ SOUZA NETO, Claudio Pereira; SARMENTO, Daniel. Direito Constitucional: teoria, história e métodos de trabalho. Belo Horizonte: Fórum, 2012.

${ }^{22}$ BAPTISTA, Patrícia. Transformações do Direito Administrativo. Rio de Janeiro: Renovar, 2003. p. 9697.

${ }^{23}$ BAPTISTA, Patrícia. Transformações do Direito Administrativo. Rio de Janeiro: Renovar, 2003. p. 98.

${ }^{24}$ WERNECK VIANNA, Luiz. et al. A judicialização das relações sociais no Brasil. Rio de Janeiro: Revan, 1999. p. 18.
} 
Assim, passou-se a ter uma atividade legiferante insuficiente, redundando na transferência do encargo de ação ao Executivo.

Diante dessa incapacidade do Poder Legislativo de prever todas as situações que demandavam a intervenção estatal e buscando preservar a segurança jurídica, a Administração Pública passou a fundamentar seus atos, também, diretamente nas normas constitucionais. Esse movimento vem acompanhado da deslegalização ${ }^{25}$, que consiste na regulamentação administrativa de matérias que, originalmente, seriam de competência legislativa mediante observância dos limites constitucionais.

É necessário ressaltar que, para essa mudança de paradigma, foi essencial o desenvolvimento da tese da força normativa da Constituição. A doutrina constitucional positivista, no Brasil representada por José Afonso da Silva ${ }^{26}$, elaborou a classificação das normas constitucionais baseada no seu grau de efetividade e aplicabilidade. Assim, muitos dos mandamentos constitucionais eram tidos como carecedores de normatividade. A classificação desenvolvida dividia-se em normas de eficácia plena e aplicabilidade imediata, normas de eficácia contida e normas de eficácia limitada. As normas do primeiro grupo seriam plenamente aptas a gerar efeitos jurídicos, assim como as do segundo. 0 que as distinguiria seria a possibilidade de restrição infraconstitucional das normas de eficácia contida. No entanto, o ponto polêmico da teoria é a classificação das normas de eficácia limitada, nas quais se incluem as normas programáticas e os princípios institutivos. Segundo essa tese, tais dispositivos carecem de normatividade, não sendo possível a sua aplicabilidade imediata e direta. Entre essas normas encontravam-se, por exemplo, os direitos fundamentais sociais ${ }^{27}$. Apesar de ter sido um primeiro passo para a construção da normatividade constitucional no Brasil, tal classificação operou como um óbice para a efetivação de direitos fundamentais.

Com o desenvolvimento da tese de Konrad Hesse ${ }^{28}$, mitiga-se a ideia de que a eficácia constitucional estaria vinculada a normas complementares e infraconstitucionais ou que se comportariam como meras normas-programa. A partir das ideias desenvolvidas pelo autor, ressalta-se que a atividade administrativa com fulcro constitucional faz parte, inclusive, do

\footnotetext{
${ }^{25}$ BAPTISTA, Patrícia. Transformações do Direito Administrativo. Rio de Janeiro: Renovar, 2003. p. 107. ${ }^{26}$ SILVA, José Afonso da. Aplicabilidade das Normas Constitucionais. São Paulo: Malheiros, 1998. p. 82.

${ }^{27}$ SOUZA NETO, Claudio Pereira; SARMENTO, Daniel. Direito Constitucional: teoria, história e métodos de trabalho. Belo Horizonte: Fórum, 2012. p. 330.

${ }^{28}$ HESSE, Konrad. A Força normativa da Constituição. Tradução de Gilmar Ferreira Mendes. Porto Alegre: Sergio Antonio Fabris, 1991.
} 
processo de otimização da normatividade da Constituição através de sua praxis, como preleciona Hesse $^{29}$.

Dessa maneira, observa-se o que parte da doutrina chama de constitucionalização do Direito Administrativo, que se situa como uma superação da atividade administrativa com lastro tão somente na lei. As implicações dessa mudança teórica trouxeram diversas consequências à dogmática do Direito Administrativo. Isso porque, uma vez que a Administração se vincula diretamente à Constituição, ela passa a assumir o papel de intérprete do ordenamento jurídico, abandonando seu caráter de autômata aplicadora da lei. Isso posto, a atividade administrativa passa a dever conformidade a todas as normas que a regulam, obedecendo à hierarquia normativa. A atividade da Administração com fulcro diretamente na Constituição implica possibilidade da atuação administrativa mesmo nos casos em que há omissão da lei, ou mesmo em desconformidade com a lei, no caso em que a sua subsunção ao caso concreto gere um vício de constitucionalidade evidente.

Binenbojm classifica a atuação administrativa sob o paradigma da constitucionalização da seguinte maneira: atividade secundum legem (casos em que a lei é constitucional), praeter legem (caso em que há omissão da lei, mas necessidade de agir, segundo mandamento constitucional) e contra legem (caso em que a lei aplicada ao caso concreto gera inconstitucionalidade) ${ }^{30}$. É necessário ressaltar, conforme ensina Schmidt-Assman ${ }^{31}$, que, no caso de atuação contra legem, existe maior ônus argumentativo para a Administração, uma vez que a espécie normativa a ser afastada foi fruto de um processo de atuação do Legislativo, com base também na Constituição e com legitimidade na vontade popular.

Assim, como primeiro reflexo da constitucionalização do Direito Administrativo, tem-se a elaboração da regra da juridicidade, norma basilar da dogmática administrativista, que tem como subprincípio a legalidade. A juridicidade significa que a atividade administrativa terá como fundamento o ordenamento jurídico em sua completude, sendo necessária a análise de todas as espécies normativas referentes a determinada atividade antes da emanação do ato administrativo. Com isso, faz-se necessária a análise também da hierarquia normativa, que terá em seu ápice a Constituição. Como supracitado, a juridicidade é uma regra, pois não aceita

\footnotetext{
${ }^{29}$ HESSE, Konrad. A Força normativa da Constituição. Tradução de Gilmar Ferreira Mendes. Porto Alegre: Sergio Antonio Fabris, 1991.

30 BINENBOJM, Gustavo. A constitucionalizacão do direito administrativo no Brasil: um inventário de avanços e retrocessos. Revista Eletrônica Sobre a Reforma do Estado. Salvador, n. 13, mar./abr./maio 2008.

31 SCHMIDIT-ASSMAN, Ehberhard. La Teoría General del Derecho Administrativo como Sistema: Objectos y fundamentos de la construccíon sistemática. Madrid: Marcial Pons Ediciones Juridicas, 2003. p. 82.
} 
gradação. A ordem para a Administração por ela veiculada é verdadeiro mandado definitivo ${ }^{32}$, no sentido de que sua atuação seja conforme o ordenamento jurídico, como um todo harmônico e hierarquizado, desprovido de conflitos normativos verdadeiros (os existentes são meramente aparentes, uma vez que o Direito comporta métodos que permitem sua dissolução), com aplicação do tipo all-or-nothing.

Dessa maneira, a atuação administrativa será sempre em conformidade com o ordenamento jurídico, e, na máxima medida possível, também em conformidade com a lei. Por isso, a legalidade enquanto comando de vinculação da Administração às leis em sentido estrito é considerada um princípio. Isso porque, como preleciona Alexy ${ }^{33}$, princípios são mandados de otimização prima facie, devendo ser realizados na maior medida possível dentro das possibilidades fáticas e jurídicas.

Dessa sorte, a Administração Pública deverá procurar aplicar os preceitos constantes nas leis stricto sensu o máximo possível, considerando que elas veiculam uma manifestação dos órgãos eleitos democraticamente para elaborá-las. Não obstante, como já asseverado anteriormente, essa vinculação não pode ser considerada absoluta, sob pena de implicar hipóteses de desconformidade entre os preceitos veiculados pelas leis e aqueles constantes das normas constitucionais, em perversão da hierarquia do ordenamento jurídico e de sua natureza sistêmica e coesa, ou seja, que não comporta antinomias.

\subsection{A Supremacia do Interesse Público}

O princípio da supremacia do interesse público ocupa, tradicionalmente, a condição de paradigma basilar do Direito Administrativo ao lado do aludido princípio da legalidade. Apesar de não encontrar previsão expressa na Constituição, é considerado como um princípio constitucional implícito, que poderia ser extraído das prerrogativas do Estado positivadas na Constituição. Também é defendido que seu fundamento é encontrado na própria ideia de democracia, uma vez que a tutela da coletividade sempre deveria sobressair-se à tutela dos indivíduos. Essa concepção guarda grande influência da construção filosófica de Hegel, que concebia a sociedade como um todo orgânico, que tinha seu bem estar viabilizado pela atuação universal do Estado. Dessa forma, os indivíduos que a compunham se realizavam pela concreção

${ }^{32}$ CANOTILHO, J. J. Gomes. Direito Constitucional e Teoria da Constituição. 7. ed. Almedina: Coimbra, 2014. p. 1160.

${ }^{33}$ ALEXY, Robert. Teoria dos Direitos Fundamentais. 2. ed. São Paulo: Malheiros, 2002. p. 90. 
dos interesses desse “todo”, que deveriam, portanto, ser priorizados como forma de promoção do indivíduo ${ }^{34}$.

Primeiramente, tratar-se-á da indefinição de seu conteúdo nas obras analisadas para este trabalho. 0 conceito trazido para o princípio por Bandeira De Mello é que: "O princípio da supremacia do interesse público sobre o interesse privado é princípio geral de Direito inerente a qualquer sociedade. É a própria condição de sua existência”. A conceituação carece de conteúdo, podendo ser considerada tautológica, uma vez que parte da indeterminação do conceito de interesse público, permitindo sua manipulação eventualmente arbitrária pelas autoridades públicas. A mesma indefinição é encontrada em outros manuais, como o de Carvalho Filho $^{35}$, que fundamenta a supremacia do interesse público na atividade estatal da seguinte maneira: "As atividades administrativas são desenvolvidas pelo Estado para benefício da coletividade [...] Desse modo, não é o indivíduo em si o destinatário da atividade administrativa, mas sim o grupo social como um todo".

Também é possível encontrar obras que definem o princípio através da sua aplicação na prática, o que pode ser considerado como uma inversão da lógica argumentativa. Podem ser citadas autoras como Marinela ${ }^{36}$ e Di Pietro ${ }^{37}$, que explanam sobre o princípio da supremacia do interesse público sobre o privado, enumerando os casos de sua aplicação, como o exemplo da intervenção administrativa na propriedade e no domínio econômico, além de fazerem alusão às cláusulas exorbitantes dos contratos administrativos e da auto-executoriedade dos atos administrativos.

Em síntese, a supremacia do interesse público sobre o privado se estabeleceu na doutrina nacional como uma regra, apesar de ser veiculada nos manuais como norma-princípio ${ }^{38}$ que estabelecia que, no caso de conflitos entre interesses individuais e interesse público, 0 último deveria prevalecer em qualquer circunstância. Percebe-se que essa concepção traduz o referido postulado em comando absoluto, típico das regras, e não em um mandado de otimização, próprio dos princípios.

Não há dúvidas de que o Estado moderno, que encontra suas bases filosóficas no contratualismo social, deve tutelar a coletividade. No entanto, a dogmática jurídica não pode

\footnotetext{
${ }^{34}$ BOURGEOIS, Bernard. O pensamento politico de Hegel. São Leopoldo: Unisinos, 2000.

${ }^{35}$ CARVALHO FILHO, José Santos. Manual de Direito Administrativo. 21. ed. Lumen Juris: Rio de Janeiro, 2009.

${ }^{36}$ MARINELA, Fernanda. Direito Administrativo. 9. ed. São Paulo: Saraiva, 2015.

37 DI PIETRO, Maria Sylvia Zanella. Direito Administrativo. 27. ed. São Paulo: Atlas, 2014.

${ }^{38}$ Conforme Di Pietro, Mello e Carvalho Filho.
} 
aceitar conceitos vagos ou indeterminados, principalmente quando eles forem aludidos como pedras de toque de todo um regime jurídico, no caso, o de Direito Público. Nesse sentido, destaca-se a dissertação de Ávila ${ }^{39}$ sobre o tema, na qual assevera que um princípio-norma necessita de uma fundamentação no Direito Positivo, seja essa expressa ou implícita, o que carece o princípio da "supremacia do interesse público" em questão. Segundo o autor, considerando o vigor com que os direitos individuais são consagrados na Constituição, se supremacia houvesse, seria destes e não dos coletivos.

Como foi exemplificado acima, a generalização com que a supremacia do interesse público é tratada na doutrina pátria não permite encontrar um fundamento jurídico-positivo para conferir-lhe validade. Não se pretende realizar uma leitura leviana dos autores supracitados. Eles fazem as devidas ressalvas quanto à observação da conformidade constitucional e legal na aplicação da supremacia do interesse público. No entanto, não se pode negar que a falta de definição conceitual do paradigma deu ensejo à sua utilização na praxis administrativa de maneira a legitimar atos, por vezes, antidemocráticos.

Esse vácuo conceitual também é notável na aplicação da supremacia do interesse público pelo Supremo Tribunal Federal - STF. Apesar de não haver uma homogeneidade, pela pouca adesão da colegialidade ao princípio e, assim, ausência de um argumento “do tribunal"40, é possível ter um panorama através de pesquisa quantitativa realizada por Cohen sobre o tópico ${ }^{41}$ e de alguns acórdãos de casos paradigmáticos.

Em relação ao aspecto quantitativo, percebeu-se a pouca utilização do paradigma. Em pesquisa realizada em 05 de fevereiro de 2016, mediante emprego da expressão "supremacia do interesse público" como critério de busca, encontraram-se 23 acórdãos no sítio do STF, o que converge com os resultados encontrados da pesquisa de Cohen. No aspecto qualitativo, o que se percebe é uma ausência de esforço argumentativo para especificar o conteúdo do interesse

\footnotetext{
${ }^{39}$ AVILA, Humberto. Repensando o "princípio da supremacia do interesse público sobre o particular". Revista Diálogo Jurídico. Salvador, Ano I, v. 7, out. 2001.

${ }^{40}$ MENDES, CONRADO HUBNER. Onze Ilhas. Folha de São Paulo, São Paulo, 01 fev. 2010. Disponível em: http://www1.folha.uol.com.br/fsp/opiniao/fz0102201008.htm. Acesso em: 10 maio 2016.

${ }^{41}$ COHEN, Isadora Chansky. Princípio da Supremacia do Interesse Público? Uma análise da utilização da supremacia do interesse público sobre o privado no âmbito da jurisprudência do STF. São Paulo, SBDP, 2010. Monografia - Escola de Formação da Sociedade Brasileira de Direito Público - SBDP, São Paulo, 2010. Disponível em: http://www.sbdp.org.br/arquivos/monografia/196_Monografia\%20lsadora\%20Cohen.pdf. Acesso em: 10 jul. 2016.
} 
público no caso concreto; o termo é utilizado majoritariamente de forma retórica e desconexa de fundamentação, sendo verdadeiro obter dictum nas decisões ${ }^{42}$.

$\mathrm{Na}$ análise jurisprudencial, alguns votos possibilitam perceber a aproximação do conteúdo do interesse público com valores consagrados constitucionalmente, mas não de forma expressa, exigindo verdadeiro empenho interpretativo. Um episódio que se enquadra na situação descrita encontra-se no acórdão proferido na Arguição de Descumprimento de Preceito Fundamental - ADPF 101/Distrito Federal, de relatoria da ministra Carmen Lúcia, que versou sobre a importação de pneus usados. Em seu voto, a Ministra decide pela supremacia do interesse público enquanto representação da saúde pública e da proteção ao meio ambiente. Veja-se:

Assim, pelo risco de dano ao meio ambiente ou à saúde pública tem aplicação plena o princípio constitucional da precaução ambiental, garantindo-se a supremacia do interesse público sobre o particular, na proteção da vida como bem maior à qual a Constituição deu especial atenção. ${ }^{43}$ (grifo nosso)

Outro episódio esparso, também em sede de Arguição de Descumprimento de Preceito Fundamental, foi o caso em que se discutiu o monopólio estatal da Empresa de Correios e Telégrafos. No entanto, esta aproximação, mesmo que breve, feita pelo ministro Marco Aurélio, deu-se em obter dictum, não compondo a ratio decidendi da Arguição de Descumprimento de Preceito Fundamental 46: "no caso, era necessária a intervenção direta do Estado na economia, ante razões óbvias, creio eu, para fazer predominar o interesse público, em jogo a soberania nacional."44 (grifo nosso)

Ainda no âmbito do STF, é importante notar que há casos em que se admite a relativização do interesse público em relação ao privado, como em 2007, na Suspensão de Liminar $n^{\circ} 3.242$, sob relatoria da ministra Ellen Grace, que tratava da remoção de servidor

\footnotetext{
${ }^{42}$ COHEN, Isadora Chansky. Princípio da Supremacia do Interesse Público? Uma análise da utilização da supremacia do interesse público sobre o privado no âmbito da jurisprudência do STF. São Paulo, SBDP, 2010. Monografia - Escola de Formação da Sociedade Brasileira de Direito Público - SBDP, São Paulo, 2010. Disponível em: http://www.sbdp.org.br/arquivos/monografia/196_Monografia\%20lsadora\%20Cohen.pdf. Acesso em: 10 jul. 2016.

${ }^{43}$ BRASIL, Supremo Tribunal Federal. Arguição de Descumprimento de Preceito Fundamental no 101/DF. Requerente: Presidente da República. Relatora: Ministra Cármen Lúcia. 14 de agosto de 2009. Disponível em: http://www.conectas.org/arquivos/editor/files/ADPF\%20101\%20-\%20pneus.pdf. Acesso em: 10 jul. 2016.

${ }^{44}$ BRASIL. Supremo Tribunal Federal. Arguição de Descumprimento de Preceito Fundamental $n^{\circ}$ 46/DF. Associação Brasileira das Empresas de Distribuição - ABED e Empresa de Correios e Telégrafos - ECT. Relator: Ministro Marco Aurélio. 05 de agosto de 2009 . Disponível em: http://redir.stf.jus.br/paginadorpub/paginador.jsp?docTP=AC\&doclD=608504. Acesso em: 10 jul. 2016.
} 
público. No caso em questão, o interesse particular consubstanciava-se no principio da unidade familiar, positivado no art. 226 da Constituição Federal ${ }^{45}$. Alega a ministra:

Nesse aspecto, em juízo mínimo de delibação Min. Sepúlveda Pertence, DJ 29.5.1996; e SS 1.272-AgR/RJ, rel. Min. Carlos Velloso, DJ 18.5.2001), tenho que a controvérsia instaura-se diante do confronto entre os princípios da tutela à família e da supremacia do interesse público. Esta Corte, em questão similar a discutida nestes autos, já se pronunciou ressaltando a supremacia da unidade da família (base da sociedade), enquanto conteúdo inerente ao art. 226 da Constituição Federal, sobre o interesse público. Nesse sentido, MS 21.893/DF, rel. Min. Ilmar Galvão, DJ 29.09.1994. ${ }^{46}$ (grifo nosso)

Apesar de muitos acórdãos não trabalharem com a definição do interesse público, invocando-o apenas como vocábulo para reafirmar uma decisão fundamentada em outros dispositivos, é interessante destacar o voto proferido pela ministra Carmen Lúcia no Agravo em Recurso Extraordinário $\mathrm{n}^{\circ} 711.519 / \mathrm{CE}$, de sua relatoria. No caso, o agravante fundamenta o recurso alegando a violação do princípio da supremacia do interesse público. No entanto, a ministra nega provimento ao agravo por falta de fundamentação, aduzindo que a simples alegação de violação do interesse público sem apontar os dispositivos constitucionais violados contraria a Súmula $\mathrm{n}^{0} 284$ do $\mathrm{STF}^{47}$, que discorre sobre a fundamentação em recursos extraordinários.

No recurso extraordinário, o Agravante limitou-se a afirmar que o acórdão recorrido teria contrariado o princípio da supremacia do interesse público sobre o privado. Assim, incidem na espécie vertente as Súmulas n. 283 e 284 do Supremo Tribunal ${ }^{48}$.

\footnotetext{
${ }^{45}$ BRASIL. Constituição da República Federativa do Brasil de 03 de Outubro de 1988. 34. ed. São Paulo: Saraiva, 2004.

46 BRASIL. Supremo Tribunal Federal. Suspensão de Segurança $n^{\circ} 3243 / T 0$. Estado de Tocantins Procuradoria Geral do Estado e Tribunal de Justiça do Estado de Tocantins. Relatora: Ministra Ellen Gracie. 31 de agosto de 2007.2 Disponível em: http://stf.jusbrasil.com.br/jurisprudencia/19139265/suspensao-de-seguranca-ss-3243-to-stf. Acesso em: 10 jul. 2016.

BRASIL. Supremo Tribunal Federal. Súmula 284. Disponível em: http:// www.stf.jus.br/portal/cms/verTexto.asp?servico=jurisprudenciaSumula\&tpagina=sumula_201_300. Acesso em: 10 jul. 2016.

${ }^{48}$ BRASIL. Supremo Tribunal Federal. Agravo em Recurso Extraordinário $n^{\circ} 11519 / C E$. Relatora: Ministra Cármen Lúcia. 19 de setembro de 2012. Disponível em: http:/ / www.stf.jus.br/portal/diarioJustica/verDecisao.asp?numDj=189\&dataPublicacao=26/09/2012\&inci dente $=4300565$ \& capitulo $=6$ \& codigoMateria $=3$ \&numeroMateria $=141 \&$ texto $=4134764$. Acesso em: 10 jul. 2016.
} 
Em suma, através da análise jurisprudencial realizada, percebe-se que, mesmo considerando o STF como “onze ilhas"49, é cediça a falta de profundidade no tratamento da supremacia do interesse público e ausente a discussão da natureza jurídica dela e suas implicações na argumentação do Tribunal. Ao lado da falta de conceituação, a falta de rigor científico no tratamento de elementos suscitados na argumentação jurídica é ardilosa para a segurança jurídica e, consequentemente, para o Estado Democrático de Direito. Por isso, justifica-se a releitura deste paradigma sob o lume pós-positivista.

A reformulação desse princípio envolve, então, duas etapas: a definição do conceito de interesse público e a aferição da existência ou não da supremacia.

A primeira proposta, assim, resvala na busca de fundamentos constitucionais que possibilitem a adequação do princípio da supremacia do interesse público ao da segurança jurídica. Para isso, é necessário considerar que, na sociedade atual, coexiste uma pluralidade de interesses que serão promovidos ou afetados pela atuação administrativa. Logo, não parece possível encontrar um fundamento jurídico único para a definição de "interesse público" nem para o "interesse privado"; esses deverão ser analisados no caso concreto. É o que defende, em parte, Bandeira de Mello, responsável pela difusão deste paradigma na doutrina brasileira, ao dizer: "nas situações concretas hão de ser compreendidos, exegeticamente reconhecidos e dimensionados" $" 50$.

Assim, para uma correta aplicação do aludido princípio da supremacia do interesse público sobre o privado, deve-se proceder à análise da pretensão da Administração Pública e a dos cidadãos. Após tal identificação, analisa-se se os interesses perseguidos são albergados em normas jurídicas. Isso porque, como foi exposto acima, a Administração Pública está vinculada à regra da juridicidade, ou seja, suas pretensões deverão sempre estar em conformidade com o ordenamento jurídico como um todo. Dessa maneira, o interesse público não pode se confundir com o interesse do administrador. A importância de vincular o conceito de interesse a uma norma jurídica reside no afastamento da possibilidade de albergar na atuação estatal o interesse subjetivo do administrador ao revés de promover a ordem objetiva de valores, positivada na Constituição.

\footnotetext{
${ }^{49}$ MENDES, CONRADO HUBNER. Onze Ithas. Folha de São Paulo, São Paulo, 01 fev. 2010. Disponível em: http://www1.folha.uol.com.br/fsp/opiniao/fz0102201008.htm. Acesso em: 10 maio 2016.

${ }_{50}$ MELLO, Celso Antônio Bandeira de. Curso de Direito Administrativo. 27. ed. São Paulo: Malheiros, 2010. p. 99.
} 
Nesse sentido, ressalta-se a dicotomia traçada doutrinariamente de "interesse público primário" e “interesse público secundário". Aquele é definido como os interesses do Estado, constitucionalmente definidos e resumindo-se principalmente aos direitos fundamentais, enquanto o segundo é caracterizado pelo interesse do erário, ou seja, o de maximizar arrecadação e minimizar despesas. Esse entendimento não parece se sustentar diante do marco teórico adotado. Considerando que a ordem jurídica vigente tem como princípio basilar a promoção da dignidade humana e como centro axiológico e normativo os direitos fundamentais, a atuação administrativa deverá sempre ser direcionada para a promoção destes direitos. Isso posto, o interesse público secundário não encontraria abrigo nos valores constitucionais, não devendo ser considerados “interesses públicos".

Ocorre que o interesse dos particulares, que também serão aferidos no caso concreto, igualmente poderão estar positivados em normas de direito fundamental. Nas palavras de Alexy, "Se um direito individual é suscitado como razão para a restrição de um direito fundamental, então há princípios constitucionais de ambos os lados" ${ }^{51}$. Sendo ambos os interesses de envergadura constitucional, não havendo hierarquia normativa prévia entre eles, não há que se falar em supremacia abstrata entre eles. Tratando-se de direitos fundamentais, sejam individuais ou sociais e estejam eles representando o interesse público ou privado, deve-se lembrar do seu caráter majoritariamente principiológico, que demanda uma análise do caso concreto e um esforço hermenêutico para sua aplicação. Também se ressalta a hierarquia dos direitos fundamentais no ordenamento jurídico, revestidos de positivação constitucional e centralidade axiológica, irradiando valores por todo o sistema normativo. Assim, parte-se para a segunda proposta de releitura do paradigma, que é a da substituição da ideia de supremacia pelo dever de proporcionalidade.

Já foi explicitado no tópico anterior a distinção básica entre regras e princípios. Também se destacou que esses últimos são mandados de otimização, devendo ser realizados na maior medida possível dentro das possibilidades fáticas e jurídicas ${ }^{52}$. Para promover a aplicação de determinado princípio, consagrou-se a máxima da proporcionalidade, que é analisada em três níveis. 0 primeiro nível é o da adequação, que consiste na identificação dos meios para a persecução do fim almejado. Em seguida, analisa-se a necessidade, a busca do meio menos gravoso para alcançar aquele fim. E por fim, aplica-se a submáxima da proporcionalidade em sentido estrito, que consiste no sopesamento de princípios. Nesse último ângulo, os princípios

${ }^{51}$ ALEXY, Robert. Teoria dos Direitos Fundamentais. 2. ed. São Paulo: Malheiros, 2002. p. 586.
${ }^{52}$ ALEXY, Robert. Teoria dos Direitos Fundamentais. 2. ed. São Paulo: Malheiros, 2002. p. 117. 
serão considerados de acordo com o peso que cada um possui no caso concreto, sendo que o grau de supressão de um deles deve ser igualmente proporcional ao grau de realização do outro $^{53}$.

A reconstrução da supremacia do interesse público sobre o privado consistiria então no mandado de proporcionalidade da Administração ${ }^{54}$. Primeiramente esta deve realizar um juízo de adequação, buscando as normas que abarcam os interesses públicos e privados que estão envolvidos no caso concreto. Em seguida, procurar-se-á o meio menos gravoso de atingir o escopo da atividade administrativa. E, por fim, a Administração deverá proceder ao juízo de proporcionalidade em sentido estrito. Logo, nota-se mais uma vez o caráter de intérprete da Administração Pública no marco Pós-Positivista. Nessa esteira, preleciona Alexy que "interpretar é argumentar” ${ }^{25}$, assim, tem-se que todo o processo interpretativo por parte da Administração deve reger-se pela racionalidade da argumentação jurídica. A aplicação dessas regras do discurso prático em âmbito administrativo se sustenta pelo princípio do Estado Democrático e a necessidade de que as decisões sejam tomadas de forma passível de aferição pela população e livre de subjetivismo.

Não se sustenta, portanto, a crítica de Carvalho Filho aos "modernistas" de que esse novo paradigma afrontaria a democracia e a dinâmica social. Ao revés, o que se propõe é maior rigor científico da hermenêutica constitucional, de maneira a impedir o manejo subjetivo de conceitos vagos como interesse público e a possibilitar a centralidade dos direitos fundamentais na atividade administrativa e, assim, a efetivação da ordem constitucional e o Estado Democrático de Direito.

\subsection{A discricionariedade administrativa}

A atividade administrativa é dividida, doutrinariamente, em duas espécies: vinculada e discricionária. A primeira é aquela em que todos os seus elementos extrínsecos e intrínsecos

\footnotetext{
${ }^{53}$ ALEXY, Robert. Teoria dos Direitos Fundamentais. 2. ed. São Paulo: Malheiros, 2002. p. 167.

${ }^{54}$ Nesse sentido: SARMENTO, Daniel. Supremacia do interesse público? As colisões entre direitos fundamentais e interesses da coletividade. In: ARAGÃO, Alexandre Santos de; MARQUES NETO, Floriano de Azevedo (Coord.). Direito Administrativo e seus novos paradigmas. Belo Horizonte: Fórum, 2012.

${ }^{55}$ ALEXY, Robert. Palestra proferida no II CONGRESSO INTERNACIONAL DE DIREITO E INOVAÇÃO, Juiz de Fora, 22 set. 2015.

${ }^{56}$ CARVALHO FILHO, José Santos. Manual de Direito Administrativo. 21. ed. Lumen Juris: Rio de Janeiro, 2009. p. 31.
} 
estão expressamente regulados em dispositivos normativos ${ }^{57}$. Considerando o princípio da legalidade, amplamente reconhecido na doutrina administrativista pátria, a vinculação estaria diretamente relacionada à disciplina legal de determinada atividade, como escreve Hely Lopes de Meirelles $^{58}$. No desempenho dessa espécie de atividade, caberia ao administrador a mera subsunção do fato à norma, para a edição do ato administrativo.

Em contrapartida, a atividade discricionária é aquela em que a lei não prevê expressamente todos os seus elementos. Assim, na ausência da definição legal, a doutrina positivista considera que o Administrador possui prerrogativa para preencher, com seu juízo subjetivo, o campo de indeterminação da lei, como afirma Bandeira de Mello ${ }^{59}$. Em sentido semelhante, Lopes Meirelles conceitua o poder discricionário como aquele concedido pelo Direito para que o administrador possa praticar o ato administrativo com liberdade de escolha pautada na sua oportunidade e conveniência ${ }^{60}$.

Mais uma vez, percebe-se a insuficiência da doutrina positivista para preencher as lacunas do Direito, de modo a garantir uma atuação administrativa livre de subjetivismo. 0 comprometimento com o princípio da segurança jurídica tem como desdobramento a necessidade da adoção de métodos racionais e não subjetivos para a tomada de decisão de qualquer um dos poderes do Estado, dando efetividade aos princípios da motivação, transparência e da democracia. Também não se pode olvidar que o princípio da separação dos poderes deve ser sempre preservado, devendo a Administração respeitar a reserva discricionária do legislativo na atividade legiferante.

Dessa maneira, o que se propõe é que o ato administrativo respeite sempre a previsão legal e que nos casos em que essa não esgote todos seus aspectos, o espaço discricionário seja reduzido através do balizamento guiado pelos princípios de direitos fundamentais. 0 doutrinador francês Stassinopoulos, citado pela doutrina administrativista clássica, estabelece o seguinte enunciado: "Pode-se dizer que o campo do poder discricionário inicia-se onde termina a interpretação"61 (tradução nossa). Ora, data maxima venia, o que se defende é o uso da

\footnotetext{
${ }^{57}$ DI PIETRO, Maria Sylvia Zanella. Direito Administrativo. 27. ed. São Paulo: Atlas, 2014. p. 221.

${ }^{58}$ MEIRELLES, Hely Lopes. Curso de Direito Administrativo Brasileiro. 23. ed. São Paulo: Malheiros, 1998. p. 101.

${ }^{59}$ MELLO, Celso Antônio Bandeira de. Curso de Direito Administrativo. 27. ed. São Paulo: Malheiros, 2010. p. 962.

${ }^{60}$ MEIRELLES, Hely Lopes. Curso de Direito Administrativo Brasileiro. 23. ed. São Paulo: Malheiros, 1998.

${ }^{61}$ On peut donc dire que la domaine du pouvoir discrétionnaire commence là où se termine celui de l'interpretation. STASSINOPOULOS, Michel D. Traité des actes administratifs. Paris: Librairie Générale de Droit et de Jurisprudence, 1973. p. 151.
} 
discricionariedade como parte da própria interpretação jurídica, e não como uma etapa posterior a ela. Isso porque, como foi dito supra, primeiramente deve-se realizar a subsunção das normas legais aos fatos para se definir qual o espaço discricionário e, a partir dele, continuar o exercício hermenêutico para se encontrar, entre as diversas possibilidades aparentemente compatíveis com o ordenamento, aquelas que realmente materializam os comandos deônticos contidos nos princípios constitucionais.

Deve-se ressaltar que o tema da discricionariedade é alvo de dissidência dentro da doutrina pós-positivista. Isso porque, enquanto Alexy defende que a discricionariedade demanda o juízo de ponderação, podendo haver mais de uma escolha possível, Dworkin defende o entendimento que o Direito sempre deverá oferecer uma única resposta correta para cada caso, não podendo falar-se em juízo discricionário ${ }^{62}$.

Não se nega aqui, a disciplina normativa da discricionariedade administrativa, ou seja, a atribuição do dever-poder, pelo legislador, para que o administrador possa decidir qual é a melhor solução para o caso concreto. Ou seja, admite-se a existência de uma esfera de decisão que não está legalmente vinculada, onde reside a "conveniência" e a "oportunidade", frequentemente mencionadas ${ }^{63}$ na doutrina positivista. Esses elementos refletem a insuficiência da previsão legal perante a pluralidade de situações em que a Administração deve atuar.

No entanto, faz-se mister que a decisão, mesmo sobre a conveniência e oportunidade, seja pautada em fundamentos normativos, uma vez que os princípios constitucionais atingem todo o sistema jurídico e, mais uma vez, valha-se das regras do discurso prático, que resultarão em uma argumentação racional e passível de controle popular. Dessa maneira, não há que se falar em uma imunidade absoluta da apreciação do juízo de conveniência pelo poder judiciário, uma vez que mesmo a conveniência deverá ser fundamentada na juridicidade.

\subsection{Do ato ao processo administrativo}

Outro importante paradigma do Direito Administrativo a ser revisitado diz respeito à forma de atuação da Administração Pública, que vem sendo modificada paulatinamente pela doutrina pós-positivista. Durante os dois séculos passados, a doutrina administrativista ocupou-se

\footnotetext{
${ }^{62}$ STRECK, Luiz Lênio. Porque a discricionariedade é um grave problema para Dworkin e não o é para Alexy. Revista Direito e Práxis, v. 4, n. 7, pp. 343-367, 2013.

${ }^{63}$ CARVALHO FILHO, José Santos. Manual de Direito Administrativo. 21. ed. Lumen Juris: Rio de Janeiro, 2009. p. 47.
} 
do aprofundamento dos estudos do ato administrativo, elevando-o ao centro da dogmática do Direito Administrativo. 0 ato administrativo era considerado o principal meio do exercício da atividade estatal ${ }^{6465}$. No entanto, a centralidade do ato administrativo implica uma atuação pública não-dialógica, ideia que decorre do próprio conceito adotado por Meirelles:

Ato administrativo é toda manifestação unilateral de vontade da Administração Pública que, agindo nessa qualidade, tenha por fim imediato adquirir, resguardar transferir, modificar, extinguir e declarar direitos ou impor obrigações aos administrados ou a si própria. ${ }^{66}$

Não bastasse a ideia de uma formação de vontade unilateral por parte da Administração Pública, esta teria o condão de vincular todos os administrados em virtude de sua imperatividade auto-executória e presumidamente legítima. Dessa forma, a atuação administrativa pela via do ato administrativo guarda resquícios do autoritarismo típico do Absolutismo Monárquico, sendo denunciado por muitos autores como uma estratégia burguesa de, camufladamente, manter os pilares de um agir estatal aristocrático, agora, porém, sob uma roupagem de legitimidade conferida pelo Estado de Direito. De fato, a teoria do Direito Administrativo estruturada neste contexto conferiu destacada credibilidade à administração actocêntrica em virtude de seu amparo da legalidade. Sustentava-se que, como o ato administrativo seria editado com amparo na lei, sendo esta elaborada por representantes do povo, o agir público consequentemente corresponderia aos anseios populares. Isso decorria do próprio modelo democrático existente até então, qual seja, o puramente representativo.

De igual feita, a assunção do Estado Social impingiu alterações ao modo de atuar da Administração Pública, posto ter ela deixado de ser mera executora das leis para assumir uma posição promotora de direitos fundamentais cuja prestação não estava disciplinada em lei de maneira exaurida. Ao revés, a lei, quando existente, limitava-se a regulamentar linhas gerais da prestação do respectivo serviço público, amparada, sobretudo, por normas não legisladas derivadas no conhecimento técnico que fundamenta o desempenho das atividades executórias ${ }^{67}$.

A evolução desse modo de atuação administrativa acompanhou o desenvolvimento do sistema democrático e dos direitos fundamentais a ele relacionados. Paralelamente à

${ }^{64}$ SILVA, Vasco Manuel Pascoal Dias Pereira. Em busca do acto administrativo perdido. Coimbra: Almedina, 2003. p. 63.

${ }^{65}$ BAPTISTA, Patrícia. Transformações do Direito Administrativo. Rio de Janeiro: Renovar, 2003. p. 229.

${ }^{66}$ MEIRELLES, Hely Lopes. Curso de Direito Administrativo Brasileiro. 23. ed. São Paulo: Malheiros, 1998. p. 131.

${ }^{67}$ SILVA, Vasco Manuel Pascoal Dias Pereira. Em busca do acto administrativo perdido. Coimbra: Almedina, 2003. p. 81-85. 
representatividade, mecanismos de participação popular direta foram desenvolvidos de maneira a ampliar a legitimidade estatal. Reconheceu-se, outrossim, o direito de petição como um instrumento constantemente disponível ao cidadão para provocar a manifestação dialógica da máquina pública. 0 uso dessa ferramenta enseja a instauração do processo administrativo, agora com a participação do indivíduo no iter da conduta pública.

Demais disso, ao ato administrativo ainda são reconhecidos diversos institutos de questionável conformidade com o Estado Democrático. A doutrina confere-lhe, de forma praticamente uníssona, atributos como a presunção de legalidade, autoexecutoriedade e imperatividade, que reforçam características de um agir público autoritário, calando-se para a afirmação de características do ato administrativo como a impessoalidade, publicidade, moralidade e eficiência, que evidenciam limitações à atuação estatal típicas de uma democracia.

Dessa maneira, a doutrina moderna tem frisado a necessidade da pulverização do poder decisório da Administração, que não se resumiria em um único ato, mas sim em um conjunto de atos ordenados e harmônicos, que teriam como finalidade aferir a compatibilidade da atuação com o ordenamento jurídico, evitar abusos de poder e, principalmente, possibilitar a manifestação popular antes da decisão estatal ${ }^{68}$.

A relação entre a procedimentalização e democracia transcende o Direito Administrativo, ocupando a centralidade da teoria democrática do autor pós-positivista alemão Jurgen Habermas. Para esse autor, na sociedade atual, marcada pelo multiculturalismo e pelo pluralismo, há uma grande dificuldade de chegar-se a consensos sobre valores éticos. Dessa maneira, a legitimidade do Direito seria deslocada de um ideal axiológico para o procedimento racional e intersubjetivo, que teria por resultado a produção normativa. Para assegurar a participação no discurso democrático, é imprescindível a existência e a concretização dos direitos fundamentais, que garantem aos cidadãos a condição de seres moralmente autônomos ${ }^{69}$. $\mathrm{Na}$ mesma linha, Peter Härbele defende que a procedimentalização seja o pilar para a efetivação dos direitos fundamentais, que assumiriam uma dimensão participativa, ou o status activus processualis $^{70}$. Na esteira do autor, o também jurista alemão Erhard Denninger analisa a

\footnotetext{
${ }^{68}$ JUSTEN FILHO, Marçal. Curso de Direito Administrativo. 10. ed. São Paulo: Revista dos Tribunais, 2014. p. 340.

${ }_{69}$ BINEMBOJM, Gustavo. Uma Teoria do Direito Administrativo: direitos fundamentais, democracia e constitucionalização. 2. ed. Rio de Janeiro: Renovar, 2008.

${ }^{70}$ DENNINGER, Ehrard. Government Assistance in the Exercise of Basic Rights. German Journal Of Law. v. 12, n. 1. p. 430.
} 
importância da face procedimental dos direitos fundamentais no âmbito do processo administrativo, de forma a assegurar a razão comunicativa além do processo judicial ${ }^{71}$.

Concomitantemente com a emergência da importância do procedimento nas teorias da democracia e dos direitos fundamentais, tem-se a própria transformação do modelo de Estado, que assume demandas cada vez mais numerosas e complexas. Assim, as relações entre o Estado e o cidadão não são mais plenamente satisfeitas com o ato administrativo, fazendo-o perder a sua posição de centralidade no Direito Administrativo ${ }^{72}$.

Nesse sentido, o processo administrativo torna-se campo para a manifestação democrática e exercício dos direitos fundamentais de petição, além do contraditório e da ampla defesa. A participação no processo decisório é um importante meio de reforço da democracia participativa, possibilitando ao cidadão adotar uma postura ativa de autor e não somente destinatário do agir público.

O processo administrativo representa o espaço para a instauração do diálogo entre estado e sociedade civil, uma vez que oportuniza ao cidadão o conhecimento prévio das intenções administrativas antes de virem elas contempladas em ato administrativo imbuído de imperatividade. Dessa maneira, oportuniza-se o espaço para a participação cidadã de maneira desburocratizada e contínua, ao contrário do que se verifica no contexto da democracia representativa, em que a contribuição popular para a formação da vontade estatal concentra-se no momento do sufrágio.

Outrossim, ao permitir a diluição do processo decisório entre diversos órgãos administrativos, o processo administrativo promove a desconcentração do poder do Estado, além de lograr o aporte de recursos de ordem técnica, política e empírica diversificados, que permitem a maior aproximação ao acerto da decisão a ser proferida. Dessa forma, seja pela maior proximidade da concepção social exarada por aqueles que participam do processo, seja pela colheita da contribuição de órgãos diversos ou pela desconcentração do poder decisório, o processo administrativo permite o exercício das competências administrativas de maneira mais legítima, posto que mais dialogada com a sociedade civil e mais próxima do acerto.

\footnotetext{
${ }^{71}$ DENNINGER, Ehrard. Government Assistance in the Exercise of Basic Rights. German Journal Of Law. v. 12, n. 1. p. 435.

${ }^{72}$ ESTORNINHO, Maria João. Réquiem pelo Contrato Administrativo. Lisboa: Almedina, 2003. p. 65.
} 


\section{CONCLUSÃO}

O presente trabalho partiu da constatação de um descompasso entre a doutrina administrativista brasileira com a dogmática constitucional atual. Assim, utilizou-se o marco teórico pós-positivista para evidenciar a necessidade de adequação do Direito Administrativo aos princípios basilares do Estado Democrático de Direito, como a dignidade da pessoa humana, e a consequente centralidade dos direitos fundamentais e a isonomia, e consequentemente a racionalidade e objetividade da atuação estatal.

Primeiramente, realizou-se uma releitura histórica, de forma a encontrar a gênese dos postulados desenvolvidos pela doutrina positivista, que fundamentavam a atuação estatal unilateral e possibilitavam o autoritarismo. Buscou-se confrontar a leitura lusófona da ilusão garantística da gênese com estudos críticos que atribuem o autoritarismo à realidade particular do Brasil. A partir desse esforço, procurou-se evidenciar o anacronismo desses postulados com a dogmática dos direito fundamentais e com os princípios de hermenêutica constitucional.

Em relação ao princípio da legalidade, mostrou-se a necessidade de vincular a atividade administrativa não só à esfera da legalidade, mas ao ordenamento jurídico como um todo, possibilitando, inclusive, a atividade estatal fundamentada diretamente em normas constitucionais e, assim, evidenciando a necessidade de adoção da regra da juridicidade. A partir dessa releitura, retoma-se a Constituição como centro de validade de todo o sistema jurídico administrativo, irradiando a carga axiológica dos princípios fundamentais na atividade administrativa.

Em seguida, analisou-se o princípio da supremacia do interesse público sobre o privado pela sua explanação doutrinária e aplicação jurisprudencial. Para isso, o artigo se vale, além da revisão bibliográfica, de pesquisa da jurisprudência do Supremo Tribunal Federal. A partir dessas análises, evidenciou-se a impossibilidade do seu emprego, enquanto cláusula indeterminada, para a supressão de direitos individuais, que podem ser, também, direitos fundamentais. Na pesquisa jurisprudencial, constatou-se que sua utilização não é acompanhada de esforço argumentativo para definir seu conteúdo, levando à falta de segurança jurídica. Destarte, a utilização de tal postulado, sob a dogmática constitucional vigente, exigiria o esforço de encontrar quais os interesses envolvidos em cada caso concreto e se esses encontrariam previsão normativa. Em seguida, deve-se proceder ao juízo de proporcionalidade para aferir qual interesse prevalecerá em cada caso, mitigando a ideia da supremacia abstrata. 
De igual maneira, evidenciou-se que o tratamento conferido à disciplina da discricionariedade possibilitava uma atuação pautada no subjetivismo, desconforme ao Estado de Direito. Assim, mostrou-se a necessidade de reduzir o espaço discricionário através do balizamento da atividade administrativa não vinculada aos princípios constitucionais, que integram o ordenamento jurídico. Dessa forma, na ausência de vinculação legal, o administrador ainda se encontra adstrito aos valores jurídicos estabelecidos na Constituição. Essa releitura mitiga, também, a construção doutrinária de interesse público primário e secundário, uma vez que o interesse público legítimo seria a persecução dos princípios constitucionais.

Finalmente, abordou-se a necessidade da pulverização da atuação estatal em diversos atos ordenados dentro do processo administrativo, mitigando a ideia da unilateralidade do ato administrativo, através de um procedimento que possibilite a participação democrática e a efetivação do devido processo legal. Essa mudança tem como fundamento a incidência do princípio democrático na atividade administrativa, ensejando a participação popular direta no âmbito da Administração Pública.

\section{REFERÊNCIAS}

ALEXY, Robert. Palestra proferida no II CONGRESSO INTERNACIONAL DE DIREITO E INOVAÇÃO, Juiz de Fora, 22 set. 2015.

ALEXY, Robert. Teoria dos Direitos Fundamentais. 2. ed. São Paulo: Malheiros, 2002.

AVILA, Humberto. Repensando o "princípio da supremacia do interesse público sobre o particular”. Revista Diálogo Jurídico. Salvador, Ano I, v. 7, out. 2001.

BAPTISTA, Patrícia. Transformações do Direito Administrativo. Rio de Janeiro: Renovar, 2003.

BARROSO, Luis Roberto. Direito Constitucional Contemporâneo. 4. ed. São Paulo: Saraiva, 2013.

BINENBOJM, Gustavo. A constitucionalização do direito administrativo no Brasil: um inventário de avanços e retrocessos. Revista Eletrônica Sobre a Reforma do Estado. Salvador, n. 13, mar. /abr. /maio 2008.

BINEMBOJM, Gustavo. Da Supremacia do Interesse Público ao Dever de Proporcionalide: Um novo paradigma do Direito Administrativo. Quaestio luris. Rio de Janeiro, v. 01, n. 02, 2005. Disponível em: http://www.epublicacoes.uerj.br/index.php/quaestioiuris/article/view/11615/9099. Acesso em: 01 maio 2016. 
BINEMBOJM, Gustavo. Uma Teoria do Direito Administrativo: direitos fundamentais, democracia e constitucionalização. 2. ed. Rio de Janeiro: Renovar, 2008.

BOURGEOIS, Bernard. O pensamento politico de Hegel. São Leopoldo: Unisinos, 2000.

BRASIL. Constituição da República Federativa do Brasil de 03 de Outubro de 1988. 34. ed. São Paulo: Saraiva, 2004.

BRASIL. Supremo Tribunal Federal. Agravo em Recurso Extraordinário n 11519/CE. Relatora: Ministra Cármen Lúcia. 19 de setembro de 2012. Disponível em:

http: / / www.stf.jus.br/portal/diarioJustica/verDecisao.asp?numDj=189\&dataPublicacao=26/09/ 2012\&incidente=4300565\&capitulo=6\&codigoMateria=3\&numeroMateria=141\&texto=4134764. Acesso em: 10 jul. 2016.

BRASIL. Supremo Tribunal Federal. Arguição de Descumprimento de Preceito Fundamental $\mathrm{n}^{\circ}$ 46/DF. Associação Brasileira das Empresas de Distribuição - ABED e Empresa de Correios e Telégrafos - ECT. Relator: Ministro Marco Aurélio. 05 de agosto de 2009. Disponível em: http://redir.stf.jus.br/paginadorpub/paginador.jsp?docTP=AC\&docID=608504. Acesso em: 10 jul. 2016.

BRASIL, Supremo Tribunal Federal. Arguição de Descumprimento de Preceito Fundamental $\mathrm{n}^{\circ}$ 101/DF. Requerente: Presidente da República. Relatora: Ministra Cármen Lúcia. 14 de agosto de 2009. Disponível em: http://www.conectas.org/arquivos/editor/files/ADPF\%20101\%20-

\%20pneus.pdf. Acesso em: 10 jul. 2016.

BRASIL. Supremo Tribunal Federal. Súmula 284. Disponível em:

http: //www.stf.jus.br/portal/cms/verTexto.asp?servico=jurisprudenciaSumula\&pagina=sumula 201_300. Acesso em: 10 jul. 2016.

BRASIL. Supremo Tribunal Federal. Suspensão de Segurança $n^{\circ} 3243 / T 0$. Estado de Tocantins Procuradoria Geral do Estado e Tribunal de Justiça do Estado de Tocantins. Relatora: Ministra Ellen Gracie. 31 de agosto de 2007. Disponível em:

http://stf.jusbrasil.com.br/jurisprudencia/19139265/suspensao-de-seguranca-ss-3243-to-stf. Acesso em: 10 jul. 2016.

CANOTILHO, J. J. Gomes. Direito Constitucional e Teoria da Constituição. 7. ed. Almedina: Coimbra, 2014.

CARVALHO FILHO, José Santos. Manual de Direito Administrativo. 21. ed. Lumen Juris: Rio de Janeiro, 2009.

COHEN, Isadora Chansky. Princípio da Supremacia do Interesse Público? Uma análise da utilização da supremacia do interesse público sobre o privado no âmbito da jurisprudência do STF. São Paulo, SBDP, 2010. Monografia - Escola de Formação da Sociedade Brasileira de Direito Público - SBDP, São Paulo, 2010. Disponível em:

http://www.sbdp.org.br/arquivos/monografia/196_Monografia\%20lsadora\%20Cohen.pdf. Acesso em: 10 jul. 2016. 
DENNINGER, Ehrard. Government Assistance in the Exercise of Basic Rights. German Journal Of Law. v. 12, n. 1. p. 430.

DI PIETRO, Maria Sylvia Zanella. Direito Administrativo. 27. ed. São Paulo: Atlas, 2014. ESTORNINHO, Maria João. Réquiem pelo Contrato Administrativo. Lisboa: Almedina, 2003.

FRANÇA. Ministério da Justiça. L'œuvre révolutionnaire: les fondements de la justice actuelle. Disponível em: http://www.justice.gouv.fr/histoire-et-patrimoine-10050/la-justice-danslhistoire-10288/loeuvre-revolutionnaire-les-fondements-de-la-justice-actuelle-11909.html. Acesso em: 01 maio 2016.

GABARDO, Emerson; HACHEM, Daniel Wunder. O suposto caráter autoritário da supremacia do interesse público e das origens do direito administrativo: uma crítica da crítica. In: BACELLAR FILHO, Romeu Felipe; HACHEM, Daniel Wunder (Coord.). Direito administrativo e interesse público: estudos em homenagem ao Professor Celso Antônio Bandeira de Mello. Belo Horizonte: Fórum, 2010.

GORDILLO, Augustín. Tratado de Derecho Administrativo. 7. ed. Belo Horizonte: Del Rey, 2003. HESSE, Konrad. A Força normativa da Constituição. Tradução de Gilmar Ferreira Mendes. Porto Alegre: Sergio Antonio Fabris, 1991.

JUSTEN FILHO, Marçal. Curso de Direito Administrativo. 10. ed. São Paulo: Revista dos Tribunais, 2014.

KELSEN, Hans. Teoria Pura do Direito. 8. ed. São Paulo: Martins Fontes, 2009.

LIMA, Ruy Cirne. Sistema de Direito Administrativo Brasileiro. Porto Alegre: Gráfica Santa Maria, 1953.

MARINELA, Fernanda. Direito Administrativo. 9. ed. São Paulo: Saraiva, 2015.

MEIRELLES, Hely Lopes. Curso de Direito Administrativo Brasileiro. 23. ed. São Paulo: Malheiros, 1998.

MELLO, Celso Antônio Bandeira de. Curso de Direito Administrativo. 27. ed. São Paulo: Malheiros, 2010.

MENDES, CONRADO HUBNER. Onze Ilhas. Folha de São Paulo, São Paulo, 01 fev. 2010. Disponível em: http://www1.folha.uol.com.br/fsp/opiniao/fz0102201008.htm. Acesso em: 10 maio 2016.

OTERO, Paulo. Legalidade e Administração Pública - O Sentido da Vinculação Administrativa à Juridicidade apud BINEMBOJM, Gustavo. Da Supremacia do Interesse Público ao Dever de Proporcionalide: Um novo paradigma do Direito Administrativo. Quaestio luris. Rio de Janeiro, v. 01, n. 02, 2005. Disponível em: http://www.e-

publicacoes.uerj.br/index.php/quaestioiuris/article/view/11615/9099. Acesso em: 01 maio 2016.

SARMENTO, Daniel. Supremacia do interesse público? As colisões entre direitos fundamentais e interesses da coletividade. In: ARAGÃO, Alexandre Santos de; MARQUES NETO, Floriano de 


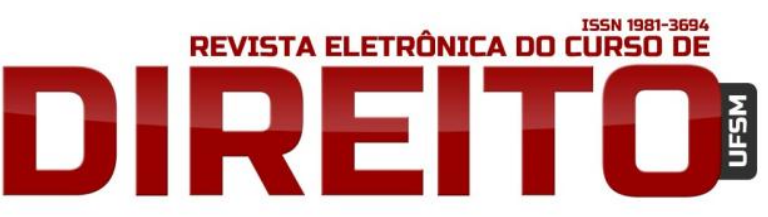

INOVAÇõES PÓS-POSITIVISTAS NOS PARADIGMAS DO DIREITO ADMINISTRATIVO BRASILEIRO

LUCIANA GASPAR MELQUIADES DUARTE GABRIEL COUTINHO GALIL

Azevedo (Coord.). Direito Administrativo e seus novos paradigmas. Belo Horizonte: Fórum, 2012.

SCHMIDIT-ASSMAN, Ehberhard. La Teoría General del Derecho Administrativo como Sistema: Objectos y fundamentos de la construccíon sistemática. Madrid: Marcial Pons Ediciones Juridicas, 2003.

SILVA, José Afonso da. Aplicabilidade das Normas Constitucionais. São Paulo: Malheiros, 1998.

SILVA, Vasco Manuel Pascoal Dias Pereira. Em busca do acto administrativo perdido. Coimbra: Almedina, 2003.

SOUZA NETO, Claudio Pereira; SARMENTO, Daniel. Direito Constitucional: teoria, história e métodos de trabalho. Belo Horizonte: Fórum, 2012.

STASSINOPOULOS, Michel D. Traité des actes administratifs. Paris: Librairie Générale de Droit et de Jurisprudence, 1973.

STRECK, Luiz Lênio. Porque a discricionariedade é um grave problema para Dworkin e não o é para Alexy. Revista Direito e Práxis, v. 4, n. 7, pp. 343-367, 2013.

WERNECK VIANNA, Luiz. et al. A judicialização das relações sociais no Brasil. Rio de Janeiro: Revan, 1999.

Recebido em: 16/08/2016 / Revisões requeridas em: 27/04/2017 / Aprovado em: 26/06/2017

\section{COMO CITAR O ARTIGO (ABNT)}

DUARTE, Luciana Gaspar Melquiades; GALIL, Gabriel Coutinho. INOVAÇÕES PÓS-POSITIVISTAS NOS PARADIGMAS DO DIREITO ADMINISTRATIVO BRASILEIRO. Revista Eletrônica do Curso de Direito da UFSM, Santa Maria, RS, v. 12, n. 2, p. 359-386, ago. 2017. ISSN 1981-3694. Disponível em: <https://periodicos.ufsm.br/revistadireito/article/view/23531>. Acesso em: dia mês. ano. doi:http://dx.doi.org/10.5902/1981369423531. 